\title{
Genetic structure and diversity of the mustard hill coral Porites astreoides along the Florida Keys reef tract
}

\author{
Dominique N. Gallery ${ }^{1,2,3}$ (D) Michelle L. Green ${ }^{2} \cdot$ Ilsa B. Kuffner ${ }^{1}$ (D) . Elizabeth A. Lenz ${ }^{4,5} \cdot$ Lauren T. Toth $^{1} \mathbb{C}$
}

Received: 11 January 2021 / Revised: 19 April 2021 / Accepted: 22 April 2021 / Published online: 9 July 2021

(c) The Author(s) 2021

\begin{abstract}
Increases in local and global stressors have led to major declines in coral populations throughout the western Atlantic. While abundances of other species have declined, however, the relative abundance of the mustard hill coral, Porites astreoides, has increased. Porites astreoides is relatively resilient to some stressors, and because of its mixed reproductive strategies, its populations often recover quickly following disturbances. The ability for $P$. astreoides to continue as a potential "winner" in western Atlantic reefs relies on maintaining sufficient genetic variation within populations to support acclimatization and adaptation to current and future environmental change. Without high genetic diversity and gene flow within the population, it would have limited capacity for adaptation and the species' competitive advantages could be short-lived. In this study, we determined the genetic relatedness of 37 P. astreoides colonies at four shallow reefs along the offshore Florida Keys Reef Tract (FKRT), a region particularly hard-hit by recent disturbances. Using previously designed microsatellite markers, we determined the genetic diversity and connectivity of individuals among and between sites. Our results suggest that the FKRT likely contains a single, well-mixed genetic population of $P$. astreoides, with high levels of gene flow and evidence for larval migration throughout the region. This suggests that regional populations of $P$. astreoides likely have a higher chance of maintaining resilience than many other western Atlantic species as they face current and future disturbances.
\end{abstract}

Keywords Population genetics $\cdot$ Connectivity $\cdot$ Scleractinians $\cdot$ Coral reefs $\cdot$ Reef resilience $\cdot$ Climate change

\section{Introduction}

Coral reefs provide a variety of important ecosystem services including supporting marine biodiversity (Harborne et al. 2006; Pratchett et al. 2014; Fisher et al. 2015), engineering habitat for marine organisms (Mumby et al. 2008; Pratchett et al. 2014), and transferring energy through trophic levels (Moberg and Folke 1999; Woodhead et al. 2019). For example,

\section{Communicated by D. Huang}

Dominique N. Gallery

dgallery@utexas.edu

1 US Geological Survey St. Petersburg Coastal and Marine Science Center, St. Petersburg 33701, USA

2 University of South Florida, St. Petersburg 33701, USA

3 Department of Integrative Biology, The University of Texas at Austin, 78712 Austin, USA

4 Hawai'i Institute of Marine Biology, University of Hawai' $i$, Mānoa 96744, USA

5 Sea Grant College Program, University of Hawai'i At Mānoa, Mānoa 96822, USA coral reefs create complex, coastal geological structures (Moberg and Folke 1999; Spalding et al. 2014; Kuffner and Toth 2016) that can reduce wave energy and decrease erosion and storm damage on reef-lined coasts (Spalding et al. 2014; Storlazzi et al. 2019). With the effects of anthropogenic climate change exacerbating stressors acting on reefs (Hughes et al. 2017, Bruno et al. 2019), global coral cover has declined (Gardner et al. 2003; Bruno and Selig 2007), and this has impaired the ability of reefs to provide key ecological and geological functions (Kuffner and Toth 2016; Perry and Alvarez-Filip 2019).

In the western Atlantic, there have been major shifts in reef composition from dominance of large, reef-building corals, such as Orbicella and Acropora spp., to small nonreef-building "weedy" corals (Darling et al. 2012; sensu Knowlton, 2001) such as P. astreoides (González-Barrios and Álvarez-Filip 2018; Toth et al. 2019; Courtney et al. 2020) and other non-calcifying, benthic-dwelling organisms (Ruzicka et al. 2013; Lenz et al. 2015). There is evidence that shifts from reefs dominated by Acropora and Orbicella to weedy taxa can result in significant losses in communitywide calcification and reef rugosity (Alvarez-Filip et al. 
2013; Courtney et al. 2020). Without active and effective local and global management, the decline of the ecological and geological functions of coral reefs could continue into the future (Kennedy et al. 2013; Kuffner and Toth 2016; Perry and Alvarez-Filip 2019).

The Florida Keys Reef Tract (FKRT) has been especially hard-hit by disturbances over the last 50 years. Coral populations on these reefs began declining as early as the 1970 s, primarily in response to major coral disease outbreaks and thermal-stress events (Dustan 1977; Precht and Miller 2007; Shinn and Kuffner 2017). By the late 1990s, coral cover on most reefs was $<20 \%$ (Ruzicka et al. 2013; Toth et al. 2014), and currently, the average coral cover throughout the region is below 5\% (Gilliam et al. 2017; Toth et al. 2019). Like many parts of the western Atlantic, coral loss on the FKRT has disproportionally affected reef-building species, which has led to relative increases in non-reef-building taxa (Ruzicka et al. 2013; Toth et al. 2014; 2019; Kuffner and Toth 2016). From 1974 to 1982, a change in the species composition of the scleractinian corals, from the dominance of large reef-building corals like Acropora palmata to small short-lived species like Agaracia agaricites, Favia fragum, and Porites porites, was observed in the northern Keys (Dustan and Halas 1987). Subsequent declines in reefbuilding Orbicella spp. corals between 1998 and 2011 also led to relative increases in the abundance of Siderastrea and Millepora spp. in some locations (Toth et al. 2014). A recent study comparing the modern composition of reefs in the FKRT to the geologic reef framework suggested that recent disturbances have also led to a relative increase in the abundance of the weedy coral $P$. astreoides over the last several decades that is without precedent in the last 8,000 years (Toth et al. 2019). Studies from other locations suggest that the relative abundance of $P$. astreoides has been increasing not just in Florida, but throughout the western Atlantic over the past several decades (Green et al. 2008; Edmunds 2010). Projections based on the population demographics of this species suggest that the relative increase in $P$. astreoides populations will likely continue in this region in the future (Edmunds 2010).

Porites astreoides is sensitive to bleaching and thermal stress (Wagner et al. 2010; Lirman et al. 2011; Colella et al. 2012; Grottoli et al. 2014; Manzello et al. 2015; Dias and Gondim 2016), which results in cascading effects such as impaired calcification (Manzello et al. 2015), photosynthesis (Kemp et al. 2011), and reproductive ecology (Ross et al. 2013). Additionally, Grottoli et al. (2014) reported reduced thermal tolerance in the species following recurring warming events. Rates of bleaching-related mortality are not as high for $P$. astreoides as some other species, however (Lirman et al. 2011, van Woesik et al. 2012), and the impact of bleaching on $P$. astreoides populations can be spatially variable (Lenz et al. 2021). For example, in the US Virgin
Islands, Smith et al. (2013) found limited mortality of $P$. astreoides following a region-wide bleaching event in 2005. The abundance of $P$. astreoides was also observed to have increased in the US Virgin Islands after that event (Smith et al. 2013), which may be a consequence of its ability to recover rapidly from disturbance due to its high fecundity (Bak and Engel 1979; Chornesky and Peters 1987; de Putron et al. 2017).

The relative success of $P$. astreoides has been attributed to multiple factors related to its life history and physiology. Porites astreoides has a complex life history, which includes a mixed-breeding system of hermaphrodites and femaleonly colonies, multiple reproductive cycles throughout the year, and fecundity positively correlated with colony age and size (Chornesky and Peters 1987; de Putron 2003). The size of coral colonies that are simultaneous hermaphrodite brooders is typically smaller at reproductive maturity than broadcast spawning colonies, possibly due to high mortality rates or cessation of growth with age (Szmant 1986). Corals with hermaphroditic brooding reproductive patterns are often referred to as "weedy" corals because they can rapidly recruit to open substrate after a disturbance, but they do not contribute as significantly to the ecological complexity of the reef as larger, broadcasting corals (Knowlton 2001, Darling et al. 2012). Porites astreoides' multiple reproductive cycles per year, coupled with its parental care of offspring due to brooding, large planula larval size, and fast maturation (de Putron et al. 2017; Goodbody-Gringley et al. 2018), may contribute to the increasing dominance of this species following disturbance events (Baumann et al. 2016).

In addition to its resilience to bleaching, $P$. astreoides has been shown to have a relatively high tolerance to other disturbances that have impacted western Atlantic reefs since the 1970s. Resistance to most Caribbean coral diseases has been observed, including stony coral tissue loss disease (SCTLD), an ever-increasing threat to western Atlantic coral reefs that is currently decimating multiple species, especially Dichocoenia stokesi, Meandrina meandrites, and Pseudodiploria strigosa (Precht et al. 2016; Aeby et al. 2019; Gintert et al. 2019; Voss et al. 2019; Dahlgren 2020; Muller et al. 2020). Porites astreoides can also survive in waters with low $\mathrm{pH}$, although ocean acidification may negatively impact its growth (Crook et al. 2012) and disrupt its larval settlement (Albright and Langdon 2011). Overall, the resilience of $P$. astreoides to multiple types of disturbances (van Woesik et al. 2012), its ability to acclimate to environmental variability (Kenkel et al. 2013; Kenkel and Matz 2016), and its increasing relative abundance in recent decades (Green et al. 2008; Toth et al. 2019) highlight the important role it will likely play on western Atlantic reefs in the future. The resilience of $P$. astreoides will ultimately depend on its ability to survive the regime of more frequent and intense thermal stress events expected in the future. 
One way to assess the potential resilience of a species to environmental changes is through population genetics (Lacy 1988; O’Brien 1994; van Oppen and Gates 2006; Ouborg 2010; Ouborg et al. 2010; Holstein et al. 2016a). Previous genetic studies have shown that $P$. astreoides has high levels of gene flow, with dispersal distances of over $1700 \mathrm{~km}$ throughout the western Atlantic, which has led to genetic exchange spanning from the US Virgin Islands to the FKRT to Bermuda (Serrano et al. 2016). Brooding corals have traditionally been considered to have a high occurrence of asexual reproduction (Brazeau et al. 1998; Gleason et al. 2001), which could significantly reduce their genetic diversity (Herlihy and Eckert 2002; Ingvarsson 2002; Rausch and Morgan 2005); however, more recent studies have shown that inbreeding in brooding corals may be less common than previously thought (Smith et al. 2019). Increasing our current understanding of genetic variability of $P$. astreoides could help predict how populations of $P$. astreoides may respond to climate change and other anthropogenic disturbances in the future. By analyzing select microsatellites of $P$. astreoides collected from four sites throughout the Florida Keys - a subtropical location at the fringe of the species' range - we sought to expand on the findings of Serrano et al. (2016) to further evaluate the genetic relatedness of $P$. astreoides across the FKRT. We used this information to infer the regional genetic diversity and connectivity of $P$. astreoides, its most common reproductive mode, contemporary migration patterns, and how resilient the population is likely to be to future disturbances.

\section{Materials and methods}

\section{Sample collection}

Four study sites were selected along the Florida Keys reef tract (FKRT): Fowey Rocks in Biscayne National Park (25.59, - 80.10), Crocker Reef in the Upper Florida Keys (24.91, - 80.53), Sombrero Reef in the Middle Florida Keys (24.63, -81.11), and Pulaski Shoal in the Dry Tortugas National Park (24.69, - 82.77) (Fig. 1). In 2015, ten colonies of $P$. astreoides were collected within a 100 to $200 \mathrm{~m}^{2}$ area at each site, with individual colonies selected for sampling being no closer than approximately $20 \mathrm{~m}$ apart to reduce the probability of sampling clones (Kuffner et al. 2013). After collection, the corals were grown for 2 years (April 2015 to May 2017) on cinderblocks installed on the reef as part of the US Geological Survey calcification assessment project (Kuffner et al. 2013; Morrison et al. 2013). Coral colony condition was assessed and growth rates were monitored every 6 months during the study using the methods outlined in Kuffner et al. (2013; Lenz et al. 2021; data for the $P$. astreoides colonies examined here are presented in Kuffner et al. 2021). Upon completion of the 2 years of calcification assessments, 4-mm-wide sagittal sections (slabs) collected from the center of the colonies with a tile saw were brought to the US Geological Survey in St. Petersburg, FL, where host tissue was sampled for analysis of tissue health, reproduction, and coral-algal symbiont communities for an associated study (Lenz et al. 2021). The remaining live segments of
Fig. 1 Map of the Florida Keys reef tract. Yellow circles mark the offshore reef sites where Porites astreoides samples used in this study were collected ( $n=10$ per site): Fowey Rocks in Biscayne National Park, Crocker Reef, and Sombrero Reef in the Florida Keys National Marine Sanctuary, and Pulaski Shoal in Dry Tortugas National Park. Map image is the intellectual property of Esri and is used herein under license. Copyright 2020 Esri and its licensors. All rights reserved

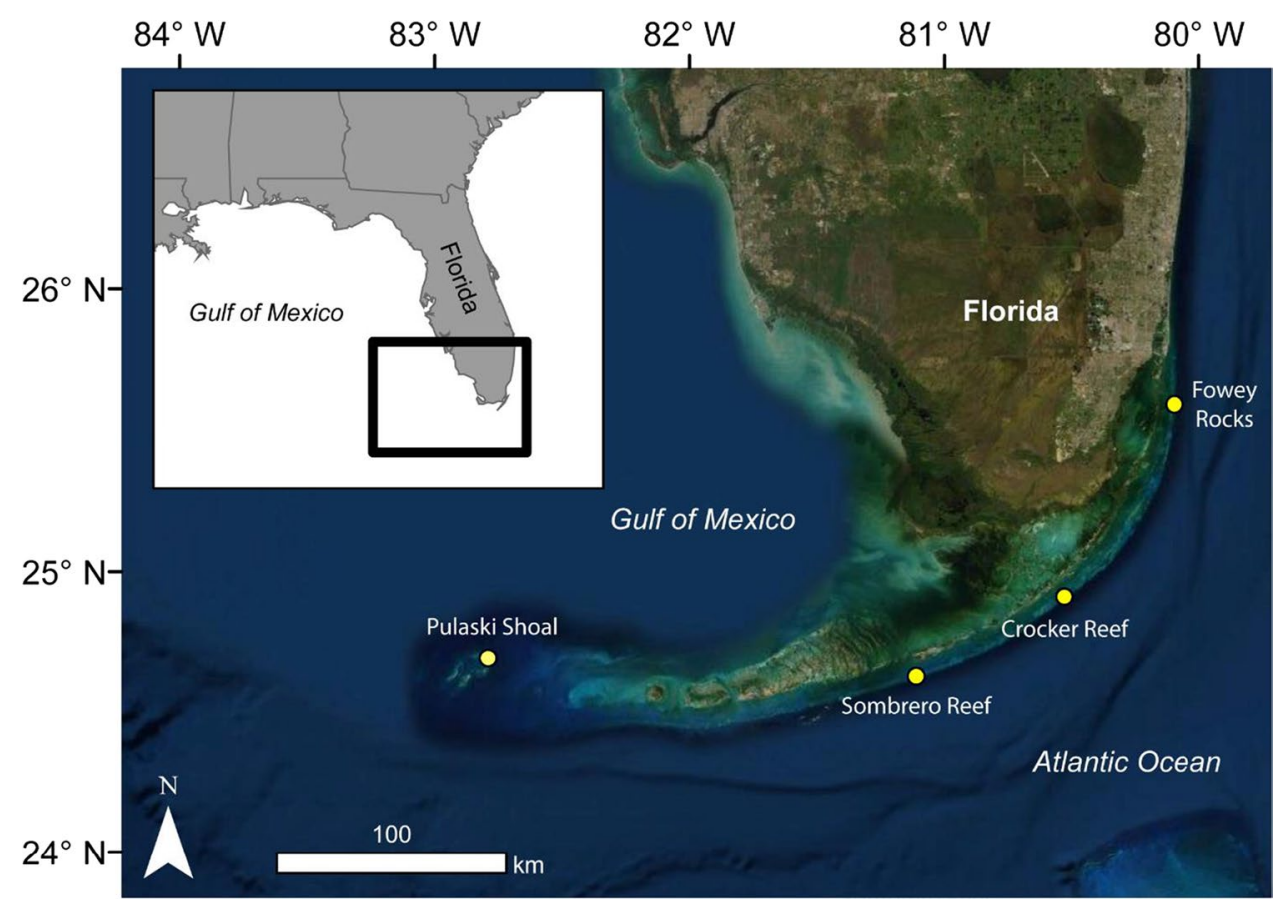


the colonies were returned to the reef sites where they were originally collected and epoxied to the ocean floor.

\section{DNA extraction}

Prior to cutting with the tile saw, tissue samples were obtained from a $5 \mathrm{~mm}^{2}$ section of the colony using a sterilized razor and placed in a $1 \%$ sodium dodecyl sulfate (SDS) DNA buffer solution (Lenz et al. 2021). One sample from Sombrero Reef was eliminated due to death prior to tissue sample collection. Genomic DNA was extracted from the remaining samples using the cetyltrimethylammonium bromide (CTAB) extraction protocol (Baker and Cunning 2016; Putnam et al. 2016). Samples were preserved in 500 $\mu \mathrm{L} 1 \%$ SDS followed by addition of Proteinase $\mathrm{K}$ to each sample. The samples were mixed with CTAB, then added to chloroform in an organic extraction process. Two ethanol precipitations and an ethanol wash were performed to extract purified DNA. Deviations from the CTAB protocol occurred during the SpeedVac steps of the ethanol precipitations and ethanol wash, with ethanol evaporation performed by leaving samples in the hood loosely covered with foil for 2 to $3 \mathrm{~h}$ until evaporation was complete. Extracted DNA was stored in a $-20{ }^{\circ} \mathrm{C}$ freezer. Following extraction, quantification of DNA extracts was performed on a Qubit 3.0 Fluorometer (Life Technologies) following the manufacturer's protocols to quantify the extracted DNA and only samples with a minimum of $150 \mathrm{ng}$ of DNA were used in polymerase chain reactions (PCRs). DNA quality was confirmed visually via gel electrophoresis on a $1.5 \%$ agarose.

\section{Microsatellite selection and PCR amplification}

Eleven microsatellites were targeted for population genetic analysis of the $P$. astreoides samples using eight PCR primers (Past_2, Past_3, Past_8, Past_10, Past_13, Past_16, Past_17, and Past_21) designed by Kenkel et al. (2013), and three (PaGA 7, PaGA24, and PaGA63) by Shearer and Coffroth (2004). PCR reactions for the microsatellites were amplified individually in $10 \mu \mathrm{L}$ reactions using the Promega GoTaq Flexi system and included 10 ng of DNA, $1 \mu \mathrm{M}$ fluorescently-labeled forward primer, $1 \mu \mathrm{M}$ reverse primer, $0.2 \mathrm{mM}$ dNTP, $2 \mu \mathrm{L} 5 \mathrm{X}$ PCR GoTaq Flexi buffer, $0.25 \mathrm{U}$ GoTaq Flexi polymerase, and $2 \mathrm{mM} \mathrm{MgCl}$. Thermocycling was performed using a Bio-Rad T100 Thermocycler at the following settings: $1 \times 95^{\circ} \mathrm{C}$ for $5 \mathrm{~min}, 35-40$ $\mathrm{X}\left(95^{\circ} \mathrm{C}\right.$ for $40 \mathrm{~s}, 58-60{ }^{\circ} \mathrm{C}$ for $60 \mathrm{~s}, 72{ }^{\circ} \mathrm{C}$ for $\left.60 \mathrm{~s}\right)$, and $72{ }^{\circ} \mathrm{C}$ for $10 \mathrm{~min}$ (Supplementary Table 1 ).

\section{Microsatellite analysis}

PCR product from the microsatellites was transferred into 96-well plates, with negative controls, and sent to the University of Illinois Urbana-Champaign (UIUC) Core Sequencing Facility for fragment analysis using an Applied Biosystems 3730xl DNA Analyzer and ROX1000 standards. The resulting microsatellite data, which are provided in (Gallery et al. 2021), were analyzed using GeneMapper software Version 5.0 (Applied Biosystems). Two samples from Fowey Rocks failed to amplify at more than four loci and were eliminated from further analysis. Three of the loci were excluded from analysis for all samples due to low amplification during PCR (PaGA 7, Past_2, Past_17). The remaining eight loci were examined for the presence of null alleles using Genepop software Version 4.7 (Dempsters EM and Brookfield methods) (Raymond and Rousset 1995; Rousset 2008), Cervus software Version 3.0.7 (Kalinowski et al. 2007), and Micro-checker software Version 2.2.3 (Oosterhout, Chakraborty, Brookfield 1 and Brookfield 2 methods) (van Oosterhout et al. 2004). Null alleles were initially found in three primer pairs: Past_3, Past_13, and PaGA 63; therefore, reamplification was performed using lowered annealing temperatures (Supplementary Table 1). Following reamplification and reanalysis for null alleles (Supplementary Table 2), only PaGA 63 consistently showed a high presence of null alleles across all testing methods; therefore, this locus was also eliminated from further analysis.

We used POWSIM Version 4.1 (Ryman and Palm 2006) to conduct a power analysis of our dataset. POWSIM can determine the $\alpha$ (type I error) and $\beta$ (type II error) of a genotype dataset with a given number of individuals and loci. POWSIM was used to determine the minimum Nei's $F_{\mathrm{ST}}$ to provide $\beta$ power of 0.8 using a chi-squared test and Fisher's exact test (after Ryman and Palm 2006). The R package "diveRsity" (Keenan et al. 2013) was used to calculate the pairwise Nei's $F_{\mathrm{ST}}$ for the power analysis.

\section{Genetic diversity and population structure}

The presence of clonal variants and probability of identity (PI), the likelihood of two unrelated individuals having identical genotypes, was determined using GenAlEx software Version 6.5 (Peakall and Smouse 2006, 2012). The seven loci that passed initial screening for null alleles were tested for Hardy-Weinberg equilibrium within groups (populations) using Arlequin software Version 3.5.2.2 (Excoffier and Lischer 2010). Hardy-Weinberg equilibrium was tested with two permutations: all sites grouped together and each site individually for a total of 35 tests (7 loci $\times 4$ populations + all sites). FSTAT Version 2.9.4 (Goudet 2003) was used to calculate allelic richness for each of the seven alleles for the four populations and all sites combined. Additionally, FSTAT was used to calculate Nei's estimation of heterozygosity including observed heterozygosity, within-population gene diversity, overall gene diversity, and the amount of genetic diversity among the samples. Nei's genetic distance and genetic identity 
Table 1 Results from HardyWeinberg equilibrium tests for the seven loci examined in Porites astreoides on the Florida Keys reef tract (after removal of the clones at Crocker Reef). $N$ number of individuals, $N_{A}$ number of alleles, $H_{\text {exp }}$ expected heterozygosity, $H_{o b s}$ observed heterozygosity, $p_{H W E}$ $p$ values for tests of Hardy-

Weinberg equilibrium, $s . d$. standard deviation of observed heterozygosity. No loci were found to deviate significantly from Hardy-Weinberg equilibrium after Bonferroni adjustment $(\alpha=0.01)$

\begin{tabular}{|c|c|c|c|c|c|c|c|}
\hline Population & Locus & $N$ & $N_{A}$ & $H_{\text {exp }}$ & $H_{o b s}$ & $p_{H W E}$ & s.d \\
\hline \multirow[t]{7}{*}{ Fowey Rocks } & Past_3 & 8 & 7 & 0.867 & 0.875 & 0.655 & 0.00055 \\
\hline & Past_8 & 8 & 7 & 0.792 & 0.625 & 0.088 & 0.00025 \\
\hline & Past_10 & 6 & 8 & 0.924 & 0.833 & 0.088 & 0.00026 \\
\hline & Past_13 & 8 & 5 & 0.725 & 0.750 & 0.425 & 0.00051 \\
\hline & Past_16 & 8 & 5 & 0.817 & 0.750 & 0.298 & 0.00046 \\
\hline & Past_21 & 6 & 5 & 0.818 & 0.667 & 0.030 & 0.00013 \\
\hline & PaGA 24 & 8 & 2 & 0.233 & 0.250 & 1.000 & 0.00000 \\
\hline \multirow[t]{7}{*}{ Crocker Reef } & Past_3 & 9 & 8 & 0.909 & 1.000 & 0.033 & 0.00016 \\
\hline & Past_8 & 9 & 6 & 0.680 & 0.667 & 0.148 & 0.00032 \\
\hline & Past_10 & 9 & 9 & 0.915 & 0.667 & 0.017 & 0.00010 \\
\hline & Past_13 & 9 & 7 & 0.895 & 0.889 & 0.877 & 0.00033 \\
\hline & Past_16 & 9 & 4 & 0.680 & 0.667 & 0.587 & 0.00046 \\
\hline & Past_21 & 9 & 7 & 0.830 & 0.889 & 0.397 & 0.00045 \\
\hline & PaGA 24 & 8 & 2 & 0.125 & 0.125 & 1.000 & 0.00000 \\
\hline \multirow[t]{7}{*}{ Sombrero Key } & Past_3 & 9 & 7 & 0.830 & 0.778 & 0.250 & 0.00041 \\
\hline & Past_8 & 9 & 6 & 0.804 & 0.556 & 0.075 & 0.00021 \\
\hline & Past_10 & 9 & 9 & 0.895 & 0.889 & 0.884 & 0.00033 \\
\hline & Past_13 & 9 & 6 & 0.824 & 0.667 & 0.066 & 0.00027 \\
\hline & Past_16 & 9 & 5 & 0.804 & 1.000 & 0.928 & 0.00026 \\
\hline & Past_21 & 8 & 7 & 0.867 & 0.750 & 0.656 & 0.00038 \\
\hline & PaGA 24 & 8 & 2 & 0.125 & 0.125 & 1.000 & 0.00000 \\
\hline \multirow[t]{7}{*}{ Pulaski Shoal } & Past_3 & 10 & 6 & 0.826 & 1.000 & 0.892 & 0.00033 \\
\hline & Past_8 & 10 & 6 & 0.737 & 0.700 & 0.721 & 0.00042 \\
\hline & Past_10 & 10 & 10 & 0.895 & 0.900 & 0.499 & 0.00048 \\
\hline & Past_13 & 10 & 7 & 0.847 & 0.900 & 0.698 & 0.00044 \\
\hline & Past_16 & 10 & 5 & 0.816 & 0.900 & 1.000 & 0.00000 \\
\hline & Past_21 & 10 & 7 & 0.642 & 0.800 & 1.000 & 0.00000 \\
\hline & PaGA 24 & 10 & 2 & 0.268 & 0.300 & 1.000 & 0.00000 \\
\hline \multirow[t]{7}{*}{ All sites } & Past_3 & 36 & 9 & 0.852 & 0.917 & 0.002 & 0.00005 \\
\hline & Past_8 & 36 & 12 & 0.765 & 0.649 & 0.152 & 0.00019 \\
\hline & Past_10 & 34 & 18 & 0.921 & 0.824 & 0.042 & 0.00012 \\
\hline & Past_13 & 36 & 10 & 0.848 & 0.806 & 0.030 & 0.00016 \\
\hline & Past_16 & 36 & 5 & 0.792 & 0.833 & 0.682 & 0.00048 \\
\hline & Past_21 & 33 & 11 & 0.821 & 0.788 & 0.664 & 0.00030 \\
\hline & PaGA 24 & 34 & 3 & 0.190 & 0.206 & 1.000 & 0.00000 \\
\hline
\end{tabular}

were calculated with GenAlEx (Peakall and Smouse 2006, 2012).

For each site where the corals were collected, the inbreeding coefficient of individuals within each subpopulation $\left(F_{\mathrm{IS}}\right)$, the measure of population substructure $\left(F_{\mathrm{ST}}\right)$, and the overall inbreeding coefficient $\left(F_{\mathrm{IT}}\right)$, collectively known as the F-statistics, were determined using Arlequin. Arlequin was also utilized to test genetic differentiation and genetic distance among sites. Genetic differentiation among each population was calculated with analysis of molecular variance (AMOVA), and genetic distance was calculated via pairwise comparisons of $F_{\mathrm{ST}}$ values. Locus by locus AMOVA and locus by locus F-statistics were also analyzed.
Population structure within the FKRT was modeled after omitting clones to assess the number of potential genetic populations $(K)$ from one to ten using Structure software Version 2.3 (Pritchard et al. 2000). Ten replicates for each $K$ value were run with a burn-in of 100,000 and run lengths of 1,000,000 Markov chain Monte Carlo (MCMC) repetitions. An admixture model with no assumption of subpopulations based on sample location (LOCIPRIOR) and allele frequencies correlated was assumed for testing $K$ values of one through ten. Structure results were analyzed for $L(K)$ and $\Delta K$ and visualized with Structure Harvester on the web v0.6.94 (Earl and vonHoldt 2012) using the Evanno method (Evanno et al. 2005). Because the minimum number of populations that can be detected using the Evanno 
Table 2 Overall allelic richness and Nei's estimate in heterozygosity results from FSTAT (a program), FSTAT Version 2.9.4 for the seven loci examined in this study. $A R$ allelic richness, $H_{O}$ observed heterozygosity, $H_{S}$ within-population gene diversity, $H_{T}$ overall gene diversity, $D_{S T}$ amount of gene diversity among samples

\begin{tabular}{llllll}
\hline Locus & $\mathrm{AR}$ & $\mathrm{H}_{\mathrm{O}}$ & $\mathrm{H}_{\mathrm{s}}$ & $\mathrm{H}_{\mathrm{T}}$ & $\mathrm{D}_{\mathrm{ST}}$ \\
\hline Past_3 & 5.982 & 0.913 & 0.854 & 0.852 & -0.002 \\
Past_8 & 5.372 & 0.637 & 0.760 & 0.767 & 0.007 \\
Past_10 & 8.319 & 0.822 & 0.913 & 0.924 & 0.011 \\
Past_13 & 6.286 & 0.801 & 0.824 & 0.846 & 0.022 \\
Past_16 & 4.602 & 0.829 & 0.776 & 0.792 & 0.016 \\
Past_21 & 5.611 & 0.776 & 0.790 & 0.821 & 0.032 \\
PaGA 24 & 1.880 & 0.200 & 0.187 & 0.185 & -0.002 \\
Overall & - & 0.711 & 0.729 & 0.741 & 0.012 \\
\hline
\end{tabular}

method is two, StructureSelector (Li and Liu 2018) was also used to calculate the most likely number of populations using the Puechmaille method (Puechmaille 2016). The Puechmaille method employs four methods for calculating the number of populations: the median of medians (MedMed), the maximum of medians (MaxMed), the median of means (MedMean), and the maximum of means (MaxMean) (Puechmaille 2016). The method controls for the splitting of geographical populations, by limiting the membership coefficient threshold between 0.5 to 0.8 , ensuring that each geographical population cannot belong to more than one cluster (Puechmaille 2016). Because the minimum threshold of 0.5 resulted in two different estimates of $K$, we increased the threshold to 0.51 so that all four methods resolved the same $K$ value (Puechmaille 2016). Admixture bar graphs of Structure results were generated with StructuRly Version 0.1.0 (Criscuolo and Angelini 2020). The population structure of the subpopulations was visualized by ordinating the microsatellite data using a Principal Component Analysis (PCA) plot using the R Version 4.0.0 statistical software (R Core Team 2020). Contemporary migration movement between populations was analyzed with BayesAss Version 3.04 (Wilson and Rannala 2003) with a burn-in of 1,000,000, 10,000,000 MCMC iterations, and 1000 sampling intervals.

\section{Results}

\section{Power analysis}

The $\alpha$ error calculated for this study was $0.018\left(\chi^{2}\right)$ and 0.046 (Fisher's exact test), which indicates that the risk of false positives is less than $5 \%$. The $\beta$ power analysis (Supplementary Fig. 1) indicates that the minimum threshold of power needed to detect differentiation in Nei's $F_{\mathrm{ST}}$ values is 0.020. Nei's pairwise $F_{\mathrm{ST}}$ values (Supplementary Table 3 )
Table 3 Matrix of Nei's genetic distance (above diagonal) and Nei's genetic identity (below diagonal) calculated with GenAlEx. Low values of genetic distance and high values of genetic identity indicate that pairwise populations are genetically similar due to genetic mixing between the four sites across the Florida Keys reef tract: Fowey Rocks (FWY), Crocker Reef (CRK), Sombrero Reef (SMK), and Pulaski Shoal (PLS)

\begin{tabular}{lcccc}
\hline Population & FWY & CRK & SMK & PLS \\
\hline FWY & - & 0.250 & 0.192 & 0.158 \\
CRK & 0.779 & - & 0.199 & 0.315 \\
SMK & 0.825 & 0.820 & - & 0.191 \\
PLS & 0.854 & 0.730 & 0.826 & - \\
\hline
\end{tabular}

met this threshold in all but one pairwise comparison: Fowey Rocks and Pulaski Shoal. Therefore, comparisons between these two populations may be underpowered and not fully represent the potential genetic diversity and variation that is present. Overall, however, these results suggest that despite the relatively low sample size in our study, we had sufficient power to make general inferences about the genetic structure of populations of $P$. astreoides in the Florida Keys.

\section{Presence of clones}

Two P. astreoides colonies of 37 sampled at the four FKRT sites were potential genetic clones, representing approximately $2.7 \%$ clonality in the population. The clones were both samples from Crocker Reef. Probability of identity (PI) analysis of microsatellite markers at seven loci was extremely low, ranging from $1.1 \times 10^{-7}$ to $2.3 \times 10^{-7}$, which indicates that the probability of misidentifying clones is low and that two individuals from Crocker Reef with identical genotypes are truly clones.

\section{Hardy-Weinberg equilibrium}

Of the 35 permutations of Hardy-Weinberg Equilibrium (HWE) tests that were run once the data for the clones at Crocker Reef were removed, none showed significant deviations from HWE (Table 1; Bonferroni-corrected $\alpha=0.01$ ). Prior to clone removal, Crocker Reef was found to have two loci outside of HWE, Past_3 and Past_10, which is likely due to the presence of a clone at that site. Because clones are indicative of non-random mating, deviations from HWE at the location with clonal presence are expected (Stoddart 1984).

\section{Genetic variation}

Overall allelic richness and Nei's estimates in heterozygosity (Table 2) show that the PaGA24 locus has lower diversity compared to the other 6 loci. The other loci have 
comparatively higher allelic richness (4.602 and greater), within-population gene diversity ( 0.760 and greater), and overall gene diversity ( 0.767 and greater). Pairwise measurements of Nei's genetic distance, which estimates the divergence between the populations, and Nei's genetic identity, which estimates the similarity between populations (Table 3), indicate that there is likely little differentiation among populations in the FKRT.

Genetic differentiation was further analyzed with AMOVA locus by locus (Supplementary Table 4) and averaged with Arlequin. Percent variation among populations and among individuals was low- $2.41 \%$ and $1.62 \%$, respectively - and the percent variation between individuals was 95.97\% (Table 4), indicating high levels of gene flow in $P$. astreoides throughout the FKRT. Overall, the results from our statistical analyses suggest that there is little genetic differentiation among the four sites, indicating panmixia of the populations throughout the FKRT. Pairwise $F_{\text {ST }}$ estimates suggest no significant genetic distance between Fowey Rocks, Crocker Reef, Sombrero Reef, and Pulaski Shoal (Table 5); however, we reiterate that we may not have had sufficient power to definitively conclude that there is no differentiation between the populations of $P$. astreoides at the two geographic endmembers of our study: Fowey Rocks and Pulaski Shoal. Fixation indices (Table 6, Supplementary Table 5) also support the conclusion that there are low levels of genetic differentiation between populations, as well as low levels of inbreeding. $F_{\mathrm{IS}}$ and $F_{\mathrm{IT}}$, the inbreeding coefficients of individuals within subpopulations and the total population, respectively, which can range from 0 to 1 , were both low- 0.017 and 0.024 , respectively—suggesting

Table 4 Analysis of molecular variance (AMOVA) results from analysis of Porites astreoides population structure using number of different alleles among populations, among individuals, and between individuals. $S S D$ sums of square deviations. $V a, V b, V c, V$ variance components. $\% \mathrm{~V}$ percentage of variation

\begin{tabular}{llr}
\hline & AMOVA results & Average \\
\hline Among populations & SSD & 11.006 \\
& Va & 0.063 \\
& $\% V$ & 2.413 \\
& $p$ value & 0.710 \\
Among individuals & SSD & 80.564 \\
& Vb & 0.042 \\
& $\% V$ & 1.619 \\
& $p$ value & 0.309 \\
Between individuals & SSD & 80.000 \\
& Vc & 2.506 \\
& $\% V$ & 95.967 \\
Total & $p$ value & 0.111 \\
& SSD & 179.570 \\
& $V$ & 2.611 \\
\hline
\end{tabular}

Table 5 Pairwise $F_{\mathrm{ST}}$ values for each of the four Porites astreoides populations excluding clones from Crocker Reef (CRK), which indicate the degree of genetic differentiation between populations. Populations are from four sites across the Florida Keys reef tract: Fowey Rocks (FWY), Crocker Reef (CRK), Sombrero Reef (SMK), and Pulaski Shoal (PLS). No values were statistically significant $(p<0.05) . p$ values were calculated with Arlequin Version 3.5.2

\begin{tabular}{lrrrr}
\hline Population & FWY & CRK & SMK & PLS \\
\hline FWY & 0.000 & & & \\
CRK & 0.029 & 0.000 & & \\
SMK & 0.017 & 0.030 & 0.000 & \\
PLS & -0.003 & 0.031 & 0.003 & 0.000 \\
\hline
\end{tabular}

that inbreeding is uncommon on the FKRT. $F_{\mathrm{ST}}$, the overall genetic divergence of subpopulations within the total population, was 0.040 , which is well below the 0.150 threshold that would indicate significant genetic differentiation among subpopulations (Wright 1978; Frankham et al. 2002; Hartl and Clark 2007).

\section{Population substructure}

The highest mean log-likelihoods, $L(K)$, from the population structure analysis, were for a single population $(L(K)=-897.51 \pm 0.64)$ or two populations $(L(K)=-899.81 \pm 1.99)$, with the mean of the log-likelihoods decreasing and standard deviation increasing significantly after that point (Fig. 2a). Similarly, $\Delta K$, (Fig. 2b) which peaks at the likely true value of $K$ (Evanno et al. 2005), was the highest at $K=2$. However, $\Delta K$ cannot be calculated for $K=1$; therefore, other methods must be utilized to determine if there were more likely one or two genetic populations. Utilizing the Puechmaille method, StructureSelector indicated a $K=1$ for MedMed, MaxMed, MedMean, and MaxMean, which suggests there is a single population throughout the Florida Keys (Fig. 2c, Supplementary Table 6). StructuRly bar graphs (Fig. 2d and e) show relatively even structure between $K=2$ and $K=3$ populations. The PCA indicates that while some genetic variability

Table 6 Average fixation indices for Porites astreoides using number of different alleles. $F_{\text {IS }}$ is the inbreeding coefficient due to the inbreeding of individuals within subpopulations. $F_{\text {IT }}$ is the inbreeding coefficient due to the inbreeding of individuals in the total population. $F_{\mathrm{ST}}$ is the amount of genetic differentiation among the subpopulations in relation to the total population

\begin{tabular}{ll}
\hline F-statistics & Average \\
\hline$F_{\text {IS }}$ & 0.017 \\
$p$ value & 0.309 \\
$F_{\text {IT }}$ & 0.024 \\
$p$ value & 0.710 \\
$F_{\text {ST }}$ & 0.040 \\
$p$ value & 0.111 \\
\hline
\end{tabular}



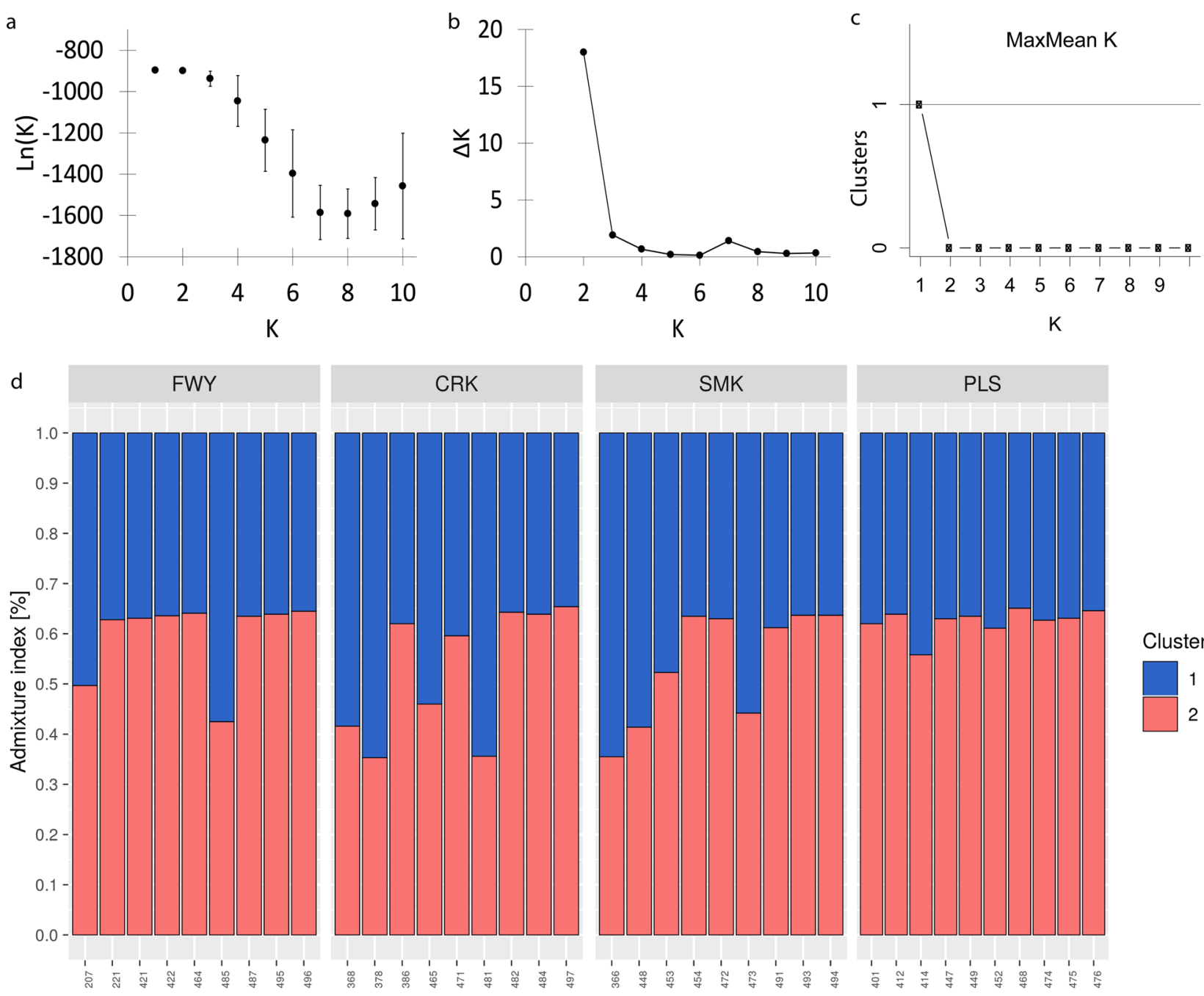

Cluster

e
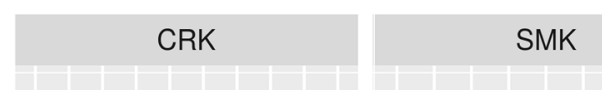

PLS
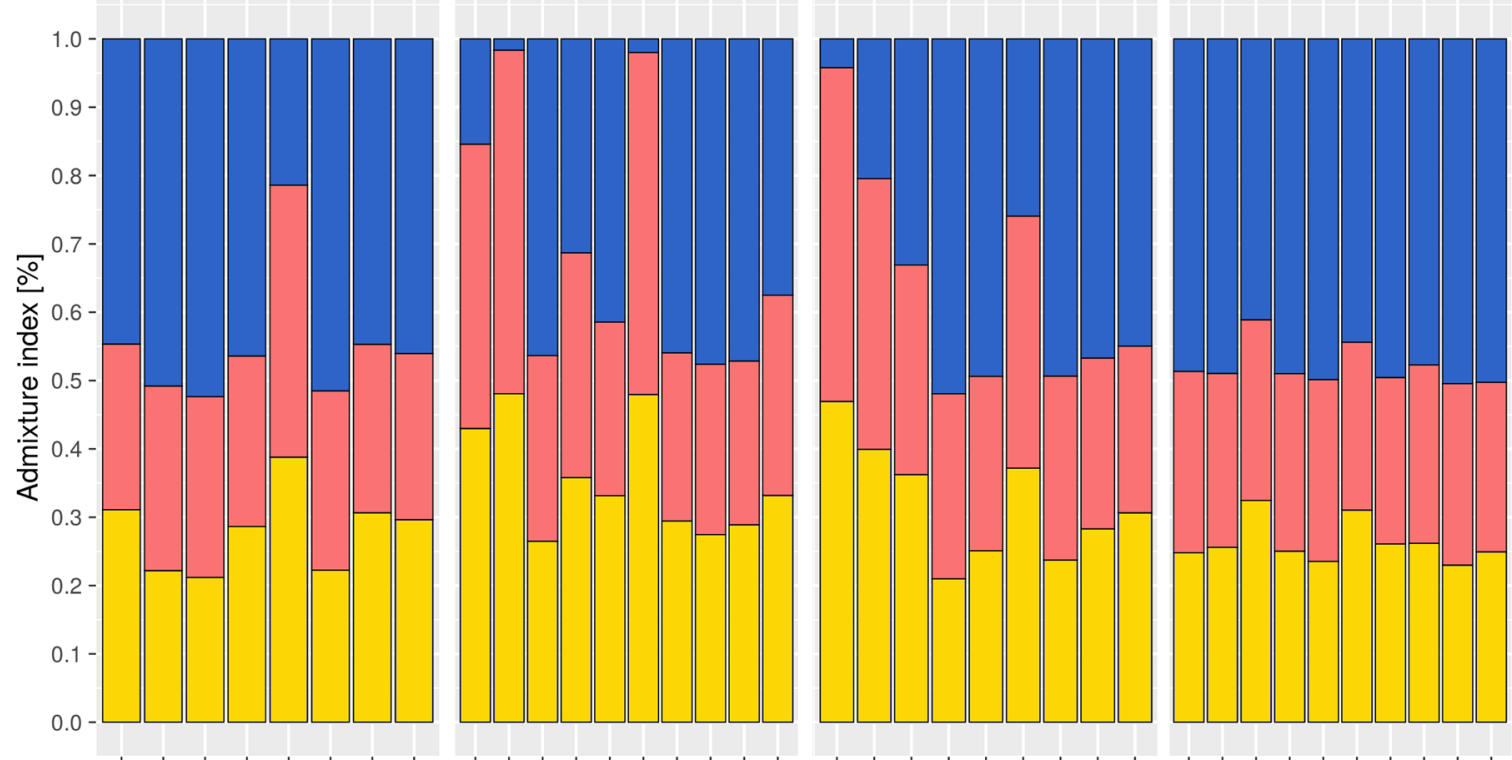

Cluster

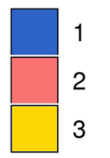

Sample ID 
4Fig. 2 Structure Harvester, StructureSelector, and StructuRly 0.1.0 analysis results of the number of potential populations $(K)$ for $K=1-10$; a Mean natural log-likelihood of $K(L(K))$ with the error bars indicating standard deviation among replicates $(n=10$ for each $K$ value). As $K$ reaches the actual value, the mean natural log-likelihood peaks and the uncertainty are minimized; once $K$ has passed, the true value log-likelihood decreases, and variance increases in simulations; b $\Delta K$ peaks at the actual value of $\mathrm{K}$; however, $\Delta K$ cannot be computed for one population. Therefore, other analyses must be performed to determine whether this is one or two populations (see the "Population substructure" section); c MaxMean $K$ calculated using the Puechmaille method (Puechmaille 2016), which indicates a single genetic population (threshold $=0.51$ ); $\mathbf{d}$ Admixture bar plot with two populations; e Admixture bar plot with three populations. FWY $=$ Fowey Rocks, CRK $=$ Crocker Reef, $\mathrm{SMK}=$ Sombrero Reef, and PLS $=$ Pulaski Shoal. Cluster refers to the inferred genetic breakdown on the population calculated by Structure software Version 2.3 (Pritchard et al. 2000)

among sites exists, with individual outliers from Crocker Reef and Pulaski Shoal, there is a clear genetic overlap among all four sites (Fig. 3). The aggregate of these results suggests that the actual number of genetic populations on the FKRT is most likely one; however, given our relatively low power, we cannot definitely rule out the possibility of more than one population.

\section{Migration}

Contemporary migration rates between the four sites were assessed with BayesAss Version 3.04 (Table 7). Of the twelve pairwise comparisons made, five showed migration rates over 10\%: migration from Fowey Rocks to Crocker Reef (14.5\%), from Crocker Reef to Fowey Rocks (11.4\%), from Fowey Rocks to Sombrero Reef (14.6\%), from Sombrero Reef to Fowey Rocks (10.9\%), and from Sombrero Reef to Pulaski Shoal (22.4\%).

\section{Discussion}

The relative success of $P$. astreoides populations in the Florida Keys and other western Atlantic locations in recent years (Green et al. 2008; Toth et al. 2019) suggests that this species has been a winner in the face of anthropogenic disturbances thus far. The continued ability of $P$. astreoides to provide live-reef habitat as disturbances increase and intensify (Hughes et al. 2017; Bruno et al. 2019), however, depends on its genetic diversity, which is the baseline requirement for resistance and resilience to future disturbances (Cardinale et al. 2012; Madin et al. 2016). Brooding, hermaphroditic corals, like $P$. astreoides, are at potential risk for self-fertilization (Brazeau et al. 1998; Carlon 1999; Gleason et al. 2001; Baums 2008) and inbreeding through related outcrossing (Carlon 1999). Although these reproductive strategies may contribute to the species' overall success, they can also contribute to loss of genetic diversity over time (Woolsey 2012). A recent study of another brooding coral, Pocillopora acuta, suggested that sexual reproduction in brooding corals increases in prevalence as the density of the species increases (Smith et al. 2019). Therefore, the potential risks of inbreeding in $P$. astreoides will likely depend on its resilience and reproductive success, now and in the future. If the species does experience high amounts of inbreeding, the recent, relative population increases may only be a short-term gain with long-term evolutionary costs, possibly including reduced population fitness and inbreeding depression (Pekkala et al. 2014).

Inbreeding can cause adverse effects on reproductive fitness (Latter and Robertson 1962; Crnokrak and Roff 1999), loss of genetic diversity (Hedrick and Kalinowski 2000; Huisman et al. 2016), and higher risk of extinction (Lande 1994; Frankham 1995). Due to this increased extinction risk and the reduced capacity to adapt to environmental fluctuations (Bakker et al. 2010), measuring and monitoring inbreeding depression are of utmost concern for conservation biologists (Hedrick and Kalinowski 2000; Brook et al. 2002). We found, however, that the inbreeding coefficients, $F_{\mathrm{IS}}$ and $F_{\mathrm{IT}}$, for $P$. astreoides on the FKRT were extremely low (0.017 and 0.024 , respectively). While our findings counter previous predictions and observations of high inbreeding for this species due to selfing (Brazeau et al. 1998; Carlon 1999; Gleason et al. 2001; Baums 2008), our results corroborate Serrano et al. (2016), who also concluded that inbreeding of $P$. astreoides was uncommon throughout the western Atlantic.

We found $2.7 \%$ clonality in the population of $P$. astreoides on the FKRT. This is substantially lower than the level of clonality reported by Serrano et al. (2016), which was $12.4 \%$ in shallow Florida Keys reefs and approximately $10 \%$ throughout the western Atlantic. The difference in the level of clonality between this study and Serrano et al. (2016) is likely a result of differences in sampling methods and size. Whereas Serrano et al. (2016) haphazardly sampled approximately $660 P$. astreoides colonies at a minimum distance of $1 \mathrm{~m}$ from one another, the 20 colonies we sampled were intentionally collected at least $20 \mathrm{~m}$ apart to avoid clones. The proximity of colonies in Serrano et al. (2016) would have led to a higher likelihood of sampling clones that had recruited near parent colonies (Baums et al. 2006, 2019). Another study that sampled $P$. astreoides from two locations in the Lower Keys found approximately 3.9\% clonality (Kenkel et al. 2013), which is more similar to the level we observed; however, information on the distance between samples was not reported in that study. Relatively low levels of clonality in $P$. astreoides populations are further supported by a recent study which sequenced the complete genome of eight $P$. astreoides individuals collected from Carrie Bow Cay in Belize and found zero clones (Dimond and Roberts 2020); 
Fig. 3 Principal component analysis (PCA) showing the genetic overlap of individual Porites astreoides coral colonies from each of the four reef sites: Fowey Rocks (blue circles), Crocker Reef (yellow squares), Sombrero Reef (red diamonds), and Pulaski Shoal (green triangles). Ellipses represent the standard deviation of the sample points on the plot for each subpopulation. The percent variation explained by each $\mathrm{PC}$ is given in parentheses on those axes. All sites show some degree of overlap indicating high gene flow and genetic connectivity of $P$. astreoides along the Florida Keys reef tract

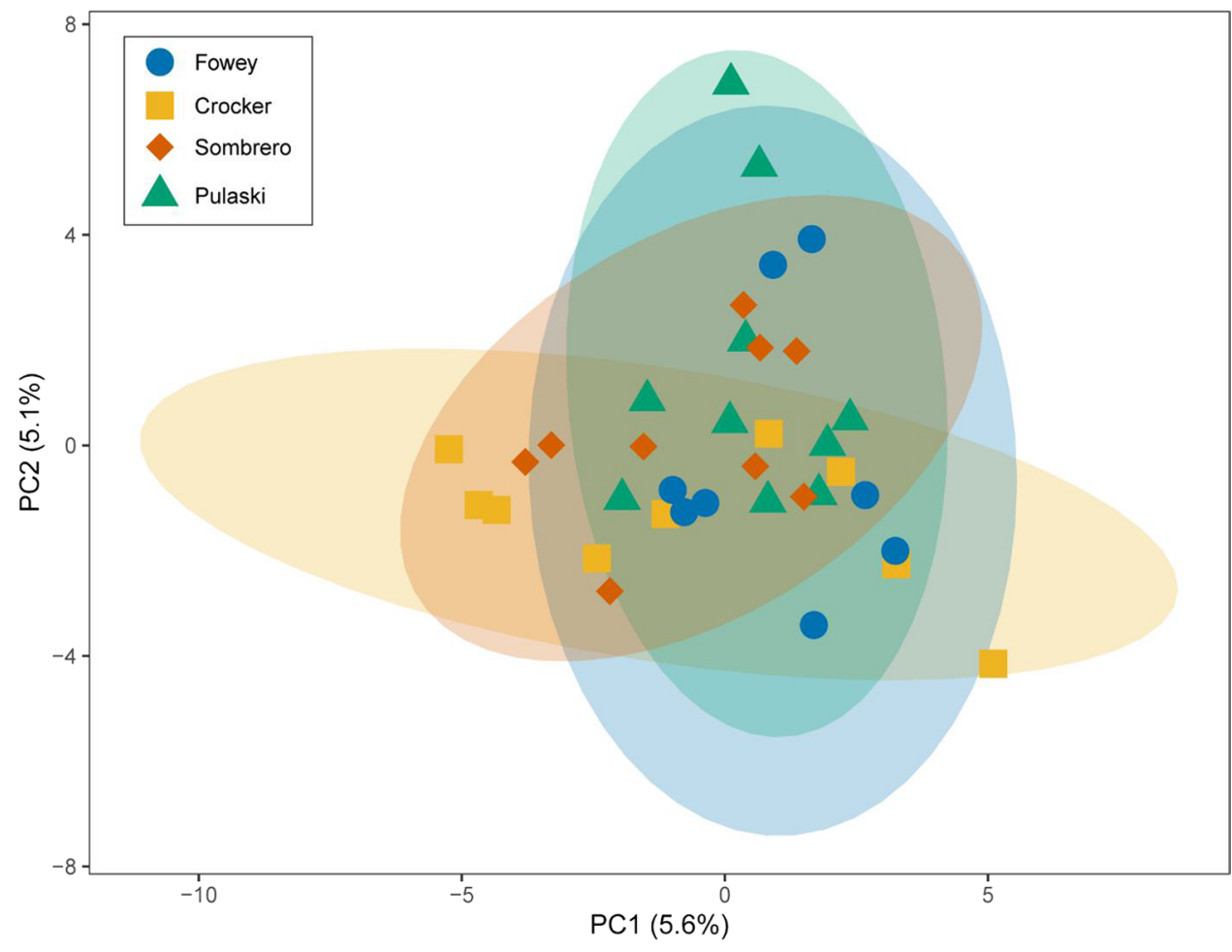

however, individual colonies in that study were collected 1-30 km from each other, a distance that would greatly reduce the chance of finding clonal replicates. Together, these results suggest that while asexual reproduction and fragmentation can contribute to spatially clustered clones, the contribution of clones to $P$. astreoides populations over reef to regional scales is likely low on the FKRT and most other locations in the western Atlantic.

Our analyses of allelic richness, observed heterozygosity, within-population gene diversity, overall gene diversity, and amount of gene diversity among samples, collectively indicate high levels of genetic diversity within $P$. astreoides on the FKRT. Observed heterozygosity was greater than 0.50 in all loci, except PaGA24, which was 0.20 (Table 2). These values are higher than those reported for microsatellite markers in other brooding corals, including Seriatopora hystrix (Baums 2008; van der Ven et al. 2021) and Pocillipora damicornis (Yeoh and Dai 2010), but were similar to heterozygosity results found in other $P$. astreoides studies (Kenkel et al.

Table 7 Posterior mean \pm standard deviation of migration rates from BayesAss Version 3.04 (Wilson and Rannala 2003). Populations across the top of the table indicate the source population and populations along the left side of the table indicate the receiving population.
2013; Serrano et al. 2016). The low probability of inbreeding, low proportion of clones, and high genetic diversity we observed both within and between sites suggest that sexual outcrossing is likely the primary mode of reproduction of $P$. astreoides on the FKRT. This supports the conclusion of a recent study on another brooding coral, Pocillopora acuta, which indicated that sexual reproduction of brooding coral may be more dominant than previously thought (Smith et al. 2019). That study suggested that the observation of low sexual reproduction in brooding corals may have been an artifact related to the difficulty in observing sperm gametic release into the water column. We also found that all loci in our $P$. astreoides samples conformed to HWE, indicating that the major assumptions of the Hardy-Weinberg principle_-a large population size, random mating, no net mutations, no migration between populations, and no net selection (Chen 2010)_-have been met for this population. We conclude, therefore, that despite the potential for asexual reproduction, most reproduction of $P$. astreoides in the FKRT is likely random, sexual mating.

Migration from Fowey Rocks (FWY) to Pulaski Shoal (PLS) was not significantly different from zero. Crocker Reef (CRK), Sombrero Reef (SMK)

\begin{tabular}{llccc}
\hline Population & FWY & CRK & SMK & PLS \\
\hline FWY & - & $0.114 \pm 0.056$ & $0.109 \pm 0.053$ & $0.059 \pm 0.050$ \\
CRK & $0.145 \pm 0.056$ & - & $0.062 \pm 0.043$ & $0.048 \pm 0.041$ \\
SMK & $0.146 \pm 0.076$ & $0.071 \pm 0.069$ & - & $0.043 \pm 0.041$ \\
PLS & $0.040 \pm 0.040$ & $0.033 \pm 0.031$ & $0.224 \pm 0.047$ & - \\
\hline
\end{tabular}


The putative dominance of random, sexual reproduction of $P$. astreoides on the FKRT should support high regional genetic diversity given sufficient connectivity of populations. Compared with corals that reproduce by broadcast spawning, the larvae of brooding coral species like $P$. astreoides are thought to have relatively short larval duration periods (Fadlallah 1983; Szmant 1986). As a result, larval dispersal distances and, therefore connectivity, would be predicted to be lower for $P$. astreoides than for broadcast spawning taxa (Holstein et al. 2014); however, Serrano et al. (2016) found that long-distance dispersal of $P$. astreoides was relatively common in the western Atlantic, and gene flow within the FKRT and between the FKRT and nearby locations was high. Results from our BayesAss analyses indicated that with migration rates greater than $10 \%$ across all four sites in our study significant migration is occurring throughout the FKRT, further supporting the hypothesis of long-range larval dispersion in $P$. astreoides. These migration rates are comparable to those found in brooding coral Helipora spp. in Sekisei Lagoon, which ranged from 0.4 to $20.2 \%$ (Taninaka et al. 2019).

Other studies have also found evidence of relatively high vertical larval dispersal of $P$. astreoides and multigenerational connectivity, which may further increase the resiliency of the species (Holstein et al. 2016b). Larval size ( 1 mm) upon release from parent colonies (Szmant 1986), vertical transmission of symbionts (Fadlallah 1983; Richmond and Hunter 1990), and high lipid and protein reserves (Fadlallah 1983; Richmond and Hunter 1990; Reich et al. 2017) should make $P$. astreoides larvae well-suited for long dispersal periods. For example, Torda et al. (2013) demonstrated that longdistance migration occurs in the brooding coral Pocillopora damicornis, attributing the success to larger, brooded larvae with zooxanthellae. Our study provides further support for high levels of gene flow throughout the FKRT. The low levels of variation among $P$. astreoides populations (2.4\%) and individuals $(1.6 \%)$ and the low $F_{\mathrm{ST}}$ value $(0.040)$ reflect the low genetic differentiation among the four sites we sampled across $350 \mathrm{~km}$ of the FKRT (Fig. 2) and suggest that long-range larval dispersal is likely occurring between locations. Additionally, Nei's genetic distance showed that the pairwise distances between each population were relatively low, indicating that the four populations are likely experiencing panmixia and high levels of gene flow. Combined with the high genetic variation between individuals (95.97\%), our results suggest high levels of genetic mixing and, therefore, high levels of regional gene flow (Uthicke and Benzie 2003). Furthermore, our analysis of the population structure suggests there is most likely a single, well-mixed breeding population of $P$. astreoides in the FKRT. It should be noted that due to the overall low resolution of the microsatellites and decreased power from low sample numbers in this study, there may be some genetic differences not captured; however, our conclusion of high levels of gene flow for $P$. astreoides across the region is corroborated by other studies (Nunes et al. 2011; Serrano et al. 2016).

Currently, P. astreoides is one of the most abundant corals on the FKRT and our results suggest that its populations are likely to persist in the future. High levels of panmixia of $P$. astreoides throughout the FKRT demonstrate the population has withstood ongoing local and global stressors (i.e., disease outbreaks, temperature-induced bleaching, and hurricanes). Although relatively susceptible individuals within the population may succumb to disturbances, high genetic diversity creates a buffer from significant population declines (Sgrò et al. 2010). The high genetic diversity we observed in this study may explain the high within-site variability in bleaching response and recovery by the same $P$. astreoides individuals during thermal stress events in 2015 and 2016, as described by Lenz et al. (2021). That study found that although local accumulation of heat stress was the best predictor of bleaching response among sites, there was also high variability in bleaching severity and the recovery of individual corals within the most severely affected sites. Because Lenz et al. (2021) found that all of the corals hosted the symbiont genus Symbiodinium spp. (formerly Clade A), differences in bleaching susceptibility within sites were more likely related to the genetic and/or healthcondition variability of the coral host interacting with the environment.

Although areas of the FKRT may provide refugia from some thermal stress events (Guest et al. 2018), it is likely that ocean warming will cause mortality of even the most resilient coral populations in the future (Hughes et al. 2017). For $P$. astreoides, however, high genetic diversity and high levels of gene flow throughout the FKRT and between the FKRT and other parts of the western Atlantic (Serrano et al. 2016) indicate large potential for natural selection and the opportunity for the population as a whole to withstand local subpopulation collapses. For example, in 2010, many inshore, shallow reefs suffered high levels of mortality following a cold-water event and the impacts on $P$. astreoides were especially severe (Lirman et al. 2011; Colella et al. 2012); however, the relative abundance of $P$. astreoides increased following that disturbance (Kemp et al. 2016).

Overall, the genetic diversity and gene flow of $P$. astreoides on the FKRT suggest that compared with many of the reef-building species it has supplanted this species should continue to maintain relatively high resilience to future disturbance. Although P. astreoides cannot serve the same ecological and geological roles as its reef-building coral counterparts (Kennedy et al. 2013; Perry and Alvarez-Filip 2019; Toth et al. 2019), providing a live-coral covering of reef substrata, regardless of species, is important for creating cryptic habitat and preventing further erosion of remaining reef structures (Kuffner and Toth 2016). Therefore, the persistence of $P$. astreoides populations in the western Atlantic, 
in combination with active management such as restoration of key reef-building taxa, could help maintain some reef function until the greater issues facing coral reefs (e.g., climate change and other anthropogenic impacts) are properly addressed.

\section{Conclusion}

Over the past 40 years, the relative abundance of Porites astreoides has increased throughout the western Atlantic; however, the species' potential to continue to play a significant functional role on reefs in the future depends on its genetic resilience to disturbance. In this study, we concluded that $P$. astreoides has high genetic diversity and little genetic population differentiation across $350 \mathrm{~km}$ of the FKRT, which suggests that despite being a brooding coral capable of high levels of asexual reproduction, its larvae are traveling throughout the region. Due to high levels of gene flow and high genetic overlap of the sites, there is likely only a single population of $P$. astreoides in the FKRT. Additionally, the low levels of inbreeding found in individuals, both within subpopulations and across the total population, suggest that sexual reproduction is the dominant reproductive mode for this species along the FKRT, as it was similarly shown across the western Atlantic. Sexual reproduction, in combination with high levels of gene flow, should allow this species to maintain high genetic diversity, which could help increase the species' ability to withstand stressors through adaptation. Overall, the regional population structure and life-history traits of $P$. astreoides suggest that the species will likely remain a dominant component of Florida's reefs in the future.

Supplementary Information The online version contains supplementary material available at https://doi.org/10.1007/s12526-021-01196-7.

Acknowledgements We thank H. Judkins for her assistance and usage of her lab to perform this experiment, A. Hetzler and L. Gallery for their assistance with lab work, and M. Matz for his assistance with writing the R code for analysis. We are grateful to James Evans, the two anonymous reviewers, and the editor for their constructive feedback and comments which greatly improved the manuscript. This work was the lead author's undergraduate research and comprised a requirement for her Bachelor of Science degree at the University of South Florida.

Funding Funding for the study was provided by the US Geological Survey's Coastal/Marine Hazards and Resources Program to IBK and LTT and National Science Foundation Graduate Research Fellowship and Internship Program to EAL.

\section{Declarations}

Conflict of interest The authors declare no competing interests.
Ethical approval All applicable international, national, and/or institutional guidelines for animal testing, animal care, and use of animals were followed by the authors.

Sampling and field studies The coral-relocation experiment was conducted under scientific permits from the Florida Keys National Marine Sanctuary (FKNMS-2013-024-A2 and FKNMS-2016-085-A1) and the National Park Service (BISC-2014-SCI-0020, BISC-2016-SCI-0003, DRTO-2015-SCI-0010, and DRTO-2016-SCI-0010), and coral samples are curated under NPS accession numbers BISC-228 and DRTO-274.

Data availability All data used in this study are published in a US Geological Survey Data Release (Gallery et al. 2021; https://doi.org/ 10.5066/P9R8NZ2J) with FGDC-compliant metadata.

Author contribution DNG, IBK, and LTT designed the study. Data was collected by DNG, MLG, IBK, and EAL and analyzed by DNG and MLG. DNG and LTT wrote the initial draft of the manuscript and all authors contributed to the final version.

Disclaimer Any use of trade, firm, or product names is for descriptive purposes only and does not imply endorsement by the US Government.

Open Access This article is licensed under a Creative Commons Attribution 4.0 International License, which permits use, sharing, adaptation, distribution and reproduction in any medium or format, as long as you give appropriate credit to the original author(s) and the source, provide a link to the Creative Commons licence, and indicate if changes were made. The images or other third party material in this article are included in the article's Creative Commons licence, unless indicated otherwise in a credit line to the material. If material is not included in the article's Creative Commons licence and your intended use is not permitted by statutory regulation or exceeds the permitted use, you will need to obtain permission directly from the copyright holder. To view a copy of this licence, visit http://creativecommons.org/licenses/by/4.0/.

\section{References}

Aeby GS, Ushijima B, Campbell JE, Jones S, Williams GJ, Meyer JL, Häse C, Paul VJ (2019) Pathogenesis of a tissue loss disease affecting multiple species of corals along the Florida reef tract. Front Mar Sci 6:678

Albright R, Langdon C (2011) Ocean acidification impacts multiple early life history processes of the Caribbean coral Porites astreoides. Glob Change Biol 17(7):2478-2487

Alvarez-Filip L, Carricart-Ganivet JP, Horta-Puga G, Iglesias-Prieto $R$ (2013) Shifts in coral-assemblage composition do not ensure persistence of reef functionality. Sci Rep 3(1):3486

Bak RPM, Engel MS (1979) Distribution, abundance and survival of juvenile hermatypic corals (Scleractinia) and the importance of life history strategies in the parent coral community. Mar Biol 54(4):341-352

Baker A, Cunning R (2016) Bulk gDNA extraction from coral samples Bakker J, van Rijswijk MEC, Weissing FJ, Bijlsma R (2010) Consequences of fragmentation for the ability to adapt to novel environments in experimental Drosophila metapopulations. Conserv Genet 11(2):435-448

Baumann JH, Townsend JE, Courtney TA, Aichelman HE, Davies SW, Lima FP, Castillo KD (2016) Temperature regimes impact coral sssemblages along environmental gradients on lagoonal reefs in Belize. PLoS One 11(9):e0162098 
Baums IB (2008) A restoration genetics guide for coral reef conservation. Mol Ecol 17(12):2796-2811

Baums IB, Baker AC, Davies SW, Grottoli AG, Kenkel CD, Kitchen SA, Kuffner IB, LaJeunesse TC, Matz MV, Miller MW, Parkinson JE, Shantz AA (2019) Considerations for maximizing the adaptive potential of restored coral populations in the western Atlantic. Ecol Appl 29(8):e01978

Baums IB, Miller MW, Hellberg ME (2006) Geographic variation in clonal structure in a reef-building Caribbean coral. Acropora Palmata Ecol Monogr 76(4):503-519

Brazeau DA, Gleason DF, Morgan ME (1998) Self-fertilization in brooding hermaphroditic Caribbean corals: evidence from molecular markers. J Exp Mar Biol Ecol 231(2):225-238

Brook BW, Tonkyn DW, O'Grady JJ, Frankham R (2002) Contribution of inbreeding to extinction risk in threatened species. Conserv Ecol 6(1)

Bruno JF, Côté IM, Toth LT (2019) Climate change, coral loss, and the curious case of the parrotfish paradigm: why don't marine protected areas improve reef resilience? Ann Rev Mar Sci 11(1):307-334

Bruno JF, Selig ER (2007) Regional decline of coral cover in the IndoPacific: timing, extent, and subregional comparisons. PLoS One 2(8):e711

Cardinale BJ, Duffy JE, Gonzalez A, Hooper DU, Perrings C, Venail P, Narwani A, Mace GM, Tilman D, Wardle DA, Kinzig AP, Daily GC, Loreau M, Grace JB, Larigauderie A, Srivastava DS, Naeem S (2012) Biodiversity loss and its impact on humanity. Nature 486(7401):59-67

Carlon DB (1999) The evolution of mating systems in tropical reef corals. Trends Ecol Evol 14(12):491-495

Chen JJ (2010) The Hardy-Weinberg principle and its applications in modern population genetics. Front Biol 5(4):348-353

Chornesky EA, Peters EC (1987) Sexual reproduction and colony growth in the Scleractinian coral Porites astreoides. Biol Bull 172(2):161-177

Colella MA, Ruzicka RR, Kidney JA, Morrison JM, Brinkhuis VB (2012) Cold-water event of January 2010 results in catastrophic benthic mortality on patch reefs in the Florida Keys. Coral Reefs 31(2):621-632

Courtney TA, Barnes BB, Chollett I, Elahi R, Gross K, Guest JR, Kuffner IB, Lenz EA, Nelson HR, Rogers CS, Toth LT, Andersson $\mathrm{AJ}$ (2020) Disturbances drive changes in coral community assemblages and coral calcification capacity. Ecosphere 11(4):e03066

Criscuolo NG, Angelini C (2020) StructuRly: a novel shiny app to produce comprehensive, detailed and interactive plots for population genetic analysis. PLoS One 15(2):e0229330

Crnokrak P, Roff DA (1999) Inbreeding depression in the wild. Heredity $83(3): 260-270$

Crook ED, Potts D, Rebolledo-Vieyra M, Hernandez L, Paytan A (2012) Calcifying coral abundance near low-pH springs: implications for future ocean acidification. Coral Reefs 31(1):239-245

Dahlgren C (2020) Rapid sssessment of the occurrence of stony coral tissue loss disease (SCTLD) along the southern coast of Grand Bahama. Bahamas, Perry Institute for Marine Science

Darling ES, Alvarez-Filip L, Oliver TA, McClanahan TR, Côté IM (2012) Evaluating life-history strategies of reef corals from species traits. Ecol Lett 15(12):1378-1386

Dias TLP, Gondim AI (2016) Bleaching in scleractinians, hydrocorals, and octocorals during thermal stress in a northeastern Brazilian reef. Mar Biodivers 46(1):303-307

Dimond JL, Roberts SB (2020) Convergence of DNA methylation profiles of the reef coral Porites astreoides in a novel environment. Front Mar Sci 6:792

Dustan P (1977) Vitality of reef coral populations off Key Largo, Florida: Recruitment and mortality. Environ Geol 2(1):51-58
Dustan P, Halas JC (1987) Changes in the reef-coral community of Carysfort reef, Key Largo, Florida: 1974 to 1982. Coral Reefs 6(2):91-106

Earl DA, vonHoldt BM (2012) STRUCTURE HARVESTER: a website and program for visualizing STRUCTURE output and implementing the Evanno method. Conserv Genet Resour 4(2):359-361

Edmunds PJ (2010) Population biology of Porites astreoides and Diploria strigosa on a shallow Caribbean reef. Mar Ecol Prog Ser 418:87-104

Evanno G, Regnaut S, Goudet J (2005) Detecting the number of clusters of individuals using the software structure: a simulation study. Mol Ecol 14(8):2611-2620

Excoffier L, Lischer HEL (2010) Arlequin suite ver 3.5: a new series of programs to perform population genetics analyses under Linux and Windows. Mol Ecol Resour 10(3):564-567

Fadlallah YH (1983) Sexual reproduction, development and larval biology in scleractinian corals. Coral Reefs 2(3):129-150

Fisher R, O'Leary RA, Low-Choy S, Mengersen K, Knowlton N, Brainard RE, Caley MJ (2015) Species richness on coral reefs and the pursuit of convergent global estimates. Curr Biol 25(4):500-505

Frankham R (1995) Inbreeding and extinction: a threshold effect. Conserv Biol 9(4):792-799

Frankham R, Briscoe DA, Ballou JD (2002) Introduction to Conservation Genetics. Cambridge University Press

Gallery DN, Toth LT, Kuffner IB (2021) DNA microsatellite markers for Mustard Hill coral (Porites astreoides) from the Florida Keys reef tract: U.S. Geological Survey data release. https://doi.org/ 10.5066/P9R8NZ2J

Gardner TA, Côté IM, Gill JA, Grant A, Watkinson AR (2003) Long-term region-wide declines in Caribbean corals. Science 301(5635):958-960

Gilliam D, Walton C, Hayes N, Ruzicka R, Colella M, Brinkhuis V (2017) Southeast Florida coral reef evaluation and monitoring project - 2016 year 14 final report, 72

Gintert BE, Precht WF, Fura R, Rogers K, Rice M, Precht LL, D'Alessandro M, Croop J, Vilmar C, Robbart ML (2019) Regional coral disease outbreak overwhelms impacts from a local dredge project. Environ Monit Assess 191(10):630

Gleason DF, Brazeau DA, Munfus D (2001) Can self-fertilizing coral species be used to enhance restoration of Caribbean reefs? Bull Mar Sci 69(2):933-943

González-Barrios FJ, Álvarez-Filip L (2018) A framework for measuring coral species-specific contribution to reef functioning in the Caribbean. Ecol Ind 95:877-886

Goodbody-Gringley G, Wong KH, Becker DM, Glennon K, de Putron SJ (2018) Reproductive ecology and early life history traits of the brooding coral, Porites astreoides, from shallow to mesophotic zones. Coral Reefs 37(2):483-494

Goudet J (2003) Fstat (ver. 2.9.4), a program to estimate and test population genetics parameters. Available from. https://www.unil.ch/ izea/softwares/fstat.html Updated fromGoudet [1995]

Green DH, Edmunds PJ, Carpenter RC (2008) Increasing relative abundance of Porites astreoides on Caribbean reefs mediated by an overall decline in coral cover. Mar Ecol Prog Ser 359:1-10

Grottoli AG, Warner ME, Levas SJ, Aschaffenburg MD, Schoepf V, McGinley M, Baumann J, Matsui Y (2014) The cumulative impact of annual coral bleaching can turn some coral species winners into losers. Glob Change Biol 20(12):3823-3833

Guest JR, Edmunds PJ, Gates RD, Kuffner IB, Andersson AJ, Barnes BB, Chollett I, Courtney TA, Elahi R, Gross K, Lenz EA, Mitarai S, Mumby PJ, Nelson HR, Parker BA, Putnam HM, Rogers CS, Toth LT (2018) A framework for identifying and characterising coral reef "oases" against a backdrop of degradation. J Appl Ecol 55(6):2865-2875 
Harborne AR, Mumby PJ, Micheli F, Perry CT, Dahlgren CP, Holmes KE, Brumbaugh DR (2006) The functional value of caribbean coral reef, seagrass and mangrove habitats to ecosystem processes. In: Advances in Marine Biology. Academic Press, 57-189

Hartl DL, Clark AG (2007) Principles of population genetics, 4th edn. Sinauer Associates, Sunderland, Mass.

Hedrick PW, Kalinowski ST (2000) Inbreeding depression in conservation biology. Annu Rev Ecol Syst 31:139-162

Herlihy CR, Eckert CG (2002) Genetic cost of reproductive assurance in a self-fertilizing plant. Nature 416(6878):320-323

Holstein DM, Paris CB, Mumby PJ (2014) Consistency and inconsistency in multispecies population network dynamics of coral reef ecosystems. Mar Ecol Prog Ser 499:1-18

Holstein DM, Paris CB, Vaz AC, Smith TB (2016a) Modeling vertical coral connectivity and mesophotic refugia. Coral Reefs 35(1):23-37

Holstein DM, Smith TB, Paris CB (2016b) Depth-independent reproduction in the reef coral Porites astreoides from shallow to mesophotic zones. PLoS One 11(1):e0146068

Hughes TP, Barnes ML, Bellwood DR, Cinner JE, Cumming GS, Jackson JBC, Kleypas J, van de Leemput IA, Lough JM, Morrison TH, Palumbi SR, van Nes EH, Scheffer M (2017) Coral reefs in the Anthropocene. Nature 546(7656):82-90

Huisman J, Kruuk LEB, Ellis PA, Clutton-Brock T, Pemberton JM (2016) Inbreeding depression across the lifespan in a wild mammal population. Proc Natl Acad Sci 113(13):3585-3590

Ingvarsson P (2002) A metapopulation perspective on genetic diversity and differentiation in partially self-fertilizing plants. Evolution 56(12):2368-2373

Kalinowski ST, Taper ML, Marshall TC (2007) Revising how the computer program CERVUS accommodates genotyping error increases success in paternity assignment. Mol Ecol 16(5):1099-1106

Keenan K, McGinnity P, Cross TF, Crozier WW, Prodöhl PA (2013) diveRsity: an $\mathrm{R}$ package for the estimation and exploration of population genetics parameters and their associated errors. Methods Ecol Evol 4(8):782-788

Kemp DW, Colella MA, Bartlett LA, Ruzicka RR, Porter JW, Fitt WK (2016) Life after cold death: reef coral and coral reef responses to the 2010 cold water anomaly in the Florida Keys. Ecosphere 7(6): 01373

Kemp DW, Oakley CA, Thornhill DJ, Newcomb LA, Schmidt GW, Fitt WK (2011) Catastrophic mortality on inshore coral reefs of the Florida Keys due to severe low-temperature stress. Glob Change Biol 17(11):3468-3477

Kenkel CD, Goodbody-Gringley G, Caillaud D, Davies SW, Bartels E, Matz MV (2013) Evidence for a host role in thermotolerance divergence between populations of the mustard hill coral (Porites astreoides) from different reef environments. Mol Ecol 22(16):4335-4348

Kenkel CD, Matz MV (2016) Gene expression plasticity as a mechanism of coral adaptation to a variable environment. Nat Ecol Evol 1(1):1-6

Kennedy EV, Perry CT, Halloran PR, Iglesias-Prieto R, Schönberg CHL, Wisshak M, Form AU, Carricart-Ganivet JP, Fine M, Eakin CM, Mumby PJ (2013) Avoiding coral reef functional collapse requires local and global action. Curr Biol 23(10):912-918

Knowlton N (2001) The future of coral reefs. Proc Natl Acad Sci 98(10):5419-5425

Kuffner IB, Hickey TD, Morrison JM (2013) Calcification rates of the massive coral Siderastrea siderea and crustose coralline algae along the Florida Keys (USA) outer-reef tract. Coral Reefs 32(4):987-997

Kuffner IB, Toth LT (2016) A geological perspective on the degradation and conservation of western Atlantic coral reefs. Conserv Biol 30(4):706-715
Kuffner IB, Lenz EA, Bartlett LA, Stathakopoulos A, Morrison JM (2021) Experimental coral-growth and physiological data and time-series imagery data for Porites astreoides in the Florida Keys, U.S.A. U.S. Geological Survey data release, https://doi. org/10.5066/P955KBD3

Lacy RC (1988) A report on population genetics in conservation. Conserv Biol 2(3):245-247

Lande R (1994) Risk of population extinction from fixation of new deleterious mutations. Evolution 48(5):1460-1469

Latter BDH, Robertson A (1962) The effects of inbreeding and artificial selection on reproductive fitness. Genet Res 3(1):110-138

Lenz EA, Bramanti L, Lasker HR, Edmunds PJ (2015) Long-term variation of octocoral populations in St. John, US Virgin Islands. Coral Reefs 34(4):1099-1109

Lenz EA, Bartlett LA, Stathakopoulos A, Kuffner IB (2021) Physiological differences in bleaching response of the coral Porites astreoides along the Florida Keys reef tract during high-temperature stress. Front Ecol Evol

Li YL, Liu JX (2018) StructureSelector : a web-based software to select and visualize the optimal number of clusters using multiple methods. Mol Ecol Resour 18(1):176-177

Lirman D, Schopmeyer S, Manzello D, Gramer LJ, Precht WF, MullerKarger F, Banks K, Barnes B, Bartels E, Bourque A, Byrne J, Donahue S, Duquesnel J, Fisher L, Gilliam D, Hendee J, Johnson M, Maxwell K, McDevitt E, Monty J, Rueda D, Ruzicka R, Thanner S (2011) Severe 2010 cold-water event caused unprecedented mortality to corals of the Florida reef tract and reversed previous survivorship patterns. PLoS One 6(8):e23047

Madin JS, Hoogenboom MO, Connolly SR, Darling ES, Falster DS, Huang D, Keith SA, Mizerek T, Pandolfi JM, Putnam HM, Baird AH (2016) A trait-based approach to advance coral reef science. Trends Ecol Evol 31(6):419-428

Manzello DP, Enochs IC, Kolodziej G, Carlton R (2015) Coral growth patterns of Montastraea cavernosa and Porites astreoides in the Florida Keys: the importance of thermal stress and inimical waters. J Exp Mar Biol Ecol 471:198-207

Moberg F, Folke C (1999) Ecological goods and services of coral reef ecosystems. Ecol Econ 29(2):215-233

Morrison JM, Kuffner IB, Hickey TD (2013) Methods for monitoring corals and crustose coralline algae to quantify in-situ calcification rates. U.S, Geological Survey, Open-File Report

Muller EM, Sartor C, Alcaraz NI, van Woesik R (2020) Spatial epidemiology of the stony-coral-tissue-loss disease in Florida. Front Mar Sci 7:163

Mumby PJ, Broad K, Brumbaugh DR, Dahlgren CP, Harborne AR, Hastings A, Holmes KE, Kappel CV, Micheli F, Sanchirico JN (2008) Coral reef habitats as surrogates of species, ecological functions, and ecosystem services. Conserv Biol 22(4):941-951

Nunes FLD, Norris RD, Knowlton N (2011) Long distance dispersal and connectivity in amphi-atlantic corals at regional and basin scales. PLoS One 6(7):e22298

O’Brien SJ (1994) A role for molecular genetics in biological conservation. Proc Natl Acad Sci 91(13):5748-5755

van Oosterhout C, Hutchinson WF, Wills DPM, Shipley P (2004) MICRO-CHECKER: software for identifying and correcting genotyping errors in microsatellite data. Mol Ecol Notes 4(3):535-538

van Oppen MJH, Gates RD (2006) Conservation genetics and the resilience of reef-building corals. Mol Ecol 15(13):3863-3883

Ouborg NJ (2010) Integrating population genetics and conservation biology in the era of genomics. Biol Let 6(1):3-6

Ouborg NJ, Pertoldi C, Loeschcke V, Bijlsma R, (Kuke), and Hedrick, P.W. (2010) Conservation genetics in transition to conservation genomics. Trends Genet 26(4):177-187 
Peakall R, Smouse PE (2006) GenAlEx 6: genetic analysis in Excel. Population genetic software for teaching and research. Molecul Ecol Notes 6(1):288-295

Peakall R, Smouse PE (2012) GenAlEx 6.5: genetic analysis in Excel. Population genetic software for teaching and research-an update. Bioinform 28(19):2537-2539

Pekkala N, Knott KE, Kotiaho JS, Nissinen K, Puurtinen M (2014) The effect of inbreeding rate on fitness, inbreeding depression and heterosis over a range of inbreeding coefficients. Evol Appl 7(9):1107-1119

Perry CT, Alvarez-Filip L (2019) Changing geo-ecological functions of coral reefs in the Anthropocene. Funct Ecol 33(6):976-988

Pratchett MS, Hoey AS, Wilson SK (2014) Reef degradation and the loss of critical ecosystem goods and services provided by coral reef fishes. Curr Opin Environ Sustain 7:37-43

Precht WF, Gintert BE, Robbart ML, Fura R, van Woesik R (2016) Unprecedented disease-related coral mortality in southeastern Florida. Sci Rep 6(1):31374

Precht WF, Miller SL (2007) Ecological shifts along the Florida reef tract: the past as a key to the future. In: Aronson RB (ed) Geological Approaches to Coral Reef Ecology. Springer, New York, NY, pp 237-312

Pritchard JK, Stephens M, Donnelly P (2000) Inference of population structure using multilocus genotype data. Genetics 155(2):945-959

Puechmaille SJ (2016) The program structure does not reliably recover the correct population structure when sampling is uneven: subsampling and new estimators alleviate the problem. Mol Ecol Resour 16(3):608-627

Putnam HM, Davidson JM, Gates RD (2016) Ocean acidification influences host DNA methylation and phenotypic plasticity in environmentally susceptible corals. Evol Appl 9(9):1165-1178

de Putron SJ (2003) The reproductive ecology of two corals and one gorgonian from sub-tropical Bermuda. Ph.D. Thesis. Swansea University

de Putron SJ, Lawson JM, White KQL, Costa MT, Geronimus MVB, MacCarthy A (2017) Variation in larval properties of the Atlantic brooding coral Porites astreoides between different reef sites in Bermuda. Coral Reefs 36(2):383-393

R Core Team (2020) R: The R project for statistical computing. Austria, Vienna

Rausch JH, Morgan MT (2005) The effect of self-fertilization, inbreeding depression, and population size on autopolyploid establishmen. Evolution 59(9):1867-1875

Raymond M, Rousset F (1995) Genepop (version 1.2): population genetics software for exact tests and ecumenicism. J Heredity 86(3):248-249

Reich HG, Robertson DL, Goodbody-Gringley G (2017) Do the shuffle: changes in Symbiodinium consortia throughout juvenile coral development. PLoS One 12(2):e0171768

Richmond R, Hunter C (1990) Reproduction and recruitment of corals: comparisons among the Caribbean, the Tropical Pacific, and the Red Sea. Mar Ecol Prog Ser 60:185-203

Ross C, Ritson-Williams R, Olsen K, Paul VJ (2013) Short-term and latent post-settlement effects associated with elevated temperature and oxidative stress on larvae from the coral Porites astreoides. Coral Reefs 32(1):71-79

Rousset F (2008) GENEPOP'007: a complete re-implementation of the genepop software for Windows and Linux. Mol Ecol Resour 8(1):103-106

Ruzicka RR, Colella MA, Porter JW, Morrison JM, Kidney JA, Brinkhuis V, Lunz KS, Macaulay KA, Bartlett LA, Meyers MK, Colee J (2013) Temporal changes in benthic assemblages on Florida Keys reefs 11 years after the 1997/1998 El Niño. Mar Ecol Prog Ser 489:125-141
Ryman N, Palm S (2006) POWSIM: a computer program for assessing statistical power when testing for genetic differentiation. Mol Ecol Notes 6(3):600-602

Serrano XM, Baums IB, Smith TB, Jones RJ, Shearer TL, Baker AC (2016) Long distance dispersal and vertical gene flow in the Caribbean brooding coral Porites astreoides. Sci Rep 6(1):21619

Sgrò CM, Overgaard J, Kristensen TN, Mitchell KA, Cockerell FE, Hoffmann AA (2010) A comprehensive assessment of geographic variation in heat tolerance and hardening capacity in populations of Drosophila melanogaster from eastern Australia. J Evol Biol 23(11):2484-2493

Shearer TL, Coffroth MA (2004) Isolation of microsatellite loci from the scleractinian corals, Montastraea cavernosa and Porites astreoides. Mol Ecol Notes 4(3):435-437

Shinn EA, Kuffner IB (2017) USGS coral photo archive. Florida Keys corals: a photographic record of changes from 1959 to 2015. https://doi.org/10.5066/F7S46QWR

Smith HA, Moya A, Cantin NE, van Oppen MJH, Torda G (2019) Observations of simultaneous sperm release and larval planulation suggest reproductive assurance in the coral Pocillopora acuta. Front Mar Sci 6:362

Smith TB, Brandt ME, Calnan JM, Nemeth RS, Blondeau J, Kadison E, Taylor M, Rothenberger P (2013) Convergent mortality responses of Caribbean coral species to seawater warming. Ecosphere 4(7):87

Spalding MD, Ruffo S, Lacambra C, Meliane I, Hale LZ, Shepard CC, Beck MW (2014) The role of ecosystems in coastal protection: adapting to climate change and coastal hazards. Ocean Coast Manag 90:50-57

Stoddart JA (1984) Genetical structure within populations of the coral Pocillopora damicornis. Mar Biol 81(1):19-30

Storlazzi CD, Reguero BG, Cole AD, Lowe E, Shope JB, Gibbs AE, Nickel BA, McCall RT, van Dongeren AR, Beck MW (2019) Rigorously valuing the role of U.S. coral reefs in coastal hazard risk reduction. Rigorously valuing the role of U.S. coral reefs in coastal hazard risk reduction. Reston, VA: U.S. Geological Survey, USGS Numbered Series No. 2019-1027

Szmant AM (1986) Reproductive ecology of Caribbean reef corals. Coral Reefs 5(1):43-53

Taninaka H, Bernardo LPC, Saito Y, Nagai S, Ueno M, Kitano YF, Nakamura T, Yasuda N (2019) Limited fine-scale larval dispersal of the threatened brooding corals Heliopora spp. as evidenced by population genetics and numerical simulation. Conserv Gen 20(6):1449-1463

Torda G, Lundgren P, Willis BL, van Oppen MJH (2013) Genetic assignment of recruits reveals short- and long-distance larval dispersal in Pocillopora damicornis on the Great Barrier Reef. Mol Ecol 22(23):5821-5834

Toth LT, Stathakopoulos A, Kuffner IB, Ruzicka RR, Colella MA, Shinn EA (2019) The unprecedented loss of Florida's reef-building corals and the emergence of a novel coral-reef assemblage. Ecology 100(9):e02781

Toth LT, van Woesik R, Murdoch TJT, Smith SR, Ogden JC, Precht WF, Aronson RB (2014) Do no-take reserves benefit Florida's corals? 14 years of change and stasis in the Florida Keys National Marine Sanctuary. Coral Reefs 33(3):565-577

Uthicke S, Benzie JAH (2003) Gene flow and population history in high dispersal marine invertebrates: mitochondrial DNA analysis of Holothuria nobilis (Echinodermata: Holothuroidea) populations from the Indo-Pacific. Mol Ecol 12(10):2635-2648

van der Ven RM, Heynderickx H, Kochzius M (2021) Differences in genetic diversity and divergence between brooding and broadcast spawning corals across two spatial scales in the Coral Triangle region. Mar Biol 168(2):17 
Voss JD, Shilling E, Combs I, Pierce F (2019) Intervention and fate tracking for corals affected by stony coral tissue loss disease in the northern Florida reef tract. Florida DEP, MIami, FL

Wagner DE, Kramer P, van Woesik R (2010) Species composition, habitat, and water quality influence coral bleaching in southern Florida. Mar Ecol Prog Ser 408:65-78

Wilson GA, Rannala B (2003) Bayesian inference of recent migration rates using multilocus genotypes. Genetics 163(3):1177-1191

van Woesik R, Franklin EC, O’Leary J, McClanahan TR, Klaus JS, Budd AF (2012) Hosts of the Plio-Pleistocene past reflect modern-day coral vulnerability. Proceedings of the Royal Society B: Biological Sciences 279(1737):2448-2456

Woodhead AJ, Hicks CC, Norström AV, Williams GJ, Graham NAJ (2019) Coral reef ecosystem services in the Anthropocene. Funct Ecol 33(6):1023-1034
Woolsey E (2012) Self-fertilization suppresses thermal tolerance in embryos of reef-building coral. In: Yellowlees D, Hughes TP (eds) Presented at the 12th International Coral Reef Symposium. James Cook University, Townsville, QLD, Australia, pp 1-4

Wright S (1978) Evolution and the genetics of populations: A treatise in four volumes. The University of Chicago Press, Chicago

Yeoh S-R, Dai C-F (2010) The production of sexual and asexual larvae within single broods of the scleractinian coral. Pocillopora damicornis. Mar Biol 157(2):351-359

Publisher's Note Springer Nature remains neutral with regard to jurisdictional claims in published maps and institutional affiliations. 